\title{
Use of Random Regression Test-Day Model to Estimate Genetic Parameters of Milk Yield in Holstein Cows
}

\author{
Yaser Fazel1 ${ }^{*}$, Masoud Asadi Fozi², Ali Esmailizadeh ${ }^{2}$, Fatemeh Fazel ${ }^{3}$, Ahmad Massoud Niazi ${ }^{4}$, \\ Shahpoor Rahmati ${ }^{4}$, Mohammad Ibrahim Qasimi ${ }^{1}$
}

${ }^{1}$ Department of Animal Science, Faculty of Veterinary, Kabul University, Kabul, Afghanistan

${ }^{2}$ Department of Animal Science, Faculty of Agriculture, Shahid Bahonar University of Kerman, Kerman, Iran

${ }^{3}$ Faculty of Veterinary, Ferdowsi University of Mashhad, Mashhad, Iran

${ }^{4}$ Department of Clinic, Faculty of Veterinary, Kabul University, Kabul, Afghanistan

Email: *yaser_fazel@yahoo.com

How to cite this paper: Fazel, Y., Fozi, M.A., Esmailizadeh, A., Fazel, F., Niazi, A.M., Rahmati, S. and Qasimi, M.I. (2018) Use of Random Regression Test-Day Model to Estimate Genetic Parameters of Milk Yield in Holstein Cows. Open Journal of Animal Sciences, 8, 27-38.

https://doi.org/10.4236/ojas.2018.81003

Received: October 23, 2017

Accepted: December 16, 2017

Published: December 19, 2017

Copyright $(9) 2018$ by authors and Scientific Research Publishing Inc. This work is licensed under the Creative Commons Attribution International License (CC BY 4.0).

http://creativecommons.org/licenses/by/4.0/

\begin{abstract}
(Co) variance components and genetic parameters were estimated for milk yield of Iranian Holstein cows. A total number of 68,945 milk test-day records of first, second and third lactations of 8515 animals from 100 sires and 7743 dams originated from 34 herds collected during 2007 to 2009 by Iranian animal breeding center were used. The ASReml computer program was used to analyze the milk test-day records using the random regression procedure. Herd test date (HTD), milking times per day (milking frequency), number of lactations, year of birth, year of calving, age of animal at calving and days in milk (DIM) considered as fixed effects and additive genetic effects and animal permanent environmental effects were considered as the random effects. Additive genetic variance, animal permanent environment variance, residual variance, phenotypic variance, heritability and repeatability were estimated during different months of lactation between 5.7 - 19.6, 15.3 - 27.1, 31.4 - 17.2, $45.8-64.83,0.1-0.32$ and $0.4-0.6$, respectively. Genetic correlation and phenotypic correlation were also estimated between months of lactation in range of $-0.35-0.98$ and $0.03-0.67$, respectively. Genetic correlation and phenotypic correlation both showed the same changing pattern and they decreased as the interval between months of lactation increased.
\end{abstract}

\section{Keywords}

Genetic Parameters, Random Regression Model, Test-Day Records, Milk Yield, Holstein Cows 


\section{Introduction}

Estimates of genetic parameters are important in the design of animal breeding programs aimed to maximizing genetic gain [1]. Heritability of a trait is a fraction of the genetic variation to the phenotypic variation, which indicates, on average, how much of the superiority of selected animals as the next generation parents is passed to the progeny generation [2]. Lactation yield and persistency are two economically important traits in dairy production [3]. Test day records are expressions of a trait that changes over time. These records are used to predict total 305-d yields which are required to evaluate the additive genetic merit of sires and cows in traditional evaluation [4]. The model for test day yields can account more precisely for environmental factors that could affect cows differently during lactation for the genetic evaluation of dairy cows using individual test day yields rather than total lactation production has a number of advantages.

A common approach to investigate genetic associations between test day yields is to consider every yield at each time period as a separate trait and then to estimate the genetic correlations between these traits. This approach has some disadvantages when large numbers of test day yields are considered. The biological interpretation of a large number of correlations is furthermore often difficult [4]. Different statistical models have been used to genetically evaluate milk production using test-day observations [5]. Reference [6] proposed the use of random regression models in animal breeding for genetic evaluations on traits measured over time. Advantages of random regression test-day models over an approach using 305-day lactation yields are now widely acknowledged. Random regressions allow for a different shape of lactation curves for each cow. The random regression model also allows a cow to be evaluated on the basis of any number of test day records during lactation and it can account for different genetic, permanent environmental and residual variances in the course of lactation. References [7] [8] [9] reported that random regression models were more appropriate for estimating the genetic parameters of test-day milk yield than repeatability models, because random regression models are able to fit genetic and environmental changes in milk yield over the time.

The aim of this study is to estimate the genetic parameters (additive genetic and permanent environmental ( $\mathrm{Co}$ ) variances) and heritability values for test day milk yields of Iranian Holstein cows using a random regression Test-Day model.

\section{Methods and Materials}

\subsection{Data Set}

Data were provided by the Animal Breeding Center of Iran (ABCI, Tehran) and consisted of a total number of 68,945 milk test-day records of first, second and third lactations of Holstein cows that calved between 22 and 36 month of age during the time period from 2003 to 2009. The records were measured on 8515 
animals originated from 100 sires and 7743 dams from 34 herds. More details of the data are presented in Table 1.

\subsection{Genetic Analysis}

Single trait random regression Test-Day model was applied to estimate the genetic parameters of milk yield of Iranian Holstein Cows in the first, second and third lactations. Herd test date (HTD), milking times per day (milking frequency), number of lactations, year of birth, year of calving, age of animal at calving and days in milk (DIM) were fitted in the model as fixed effects. Linear, quadratic and higher orders of regression were tested for effect of age at calving. Fixed polynomial regression with different order of fit was considered for DIM. For changing scale of days in milk from 5 to 305 day was standardized to the interval $[-1, \cdots, 1][10]$. Additive genetic effects and animal permanent environmental effects were fitted as the random effects. To take heterogeneous residual variances into account, the residual variance was estimated for 10 equally sized groups, based on duration of lactation (Table 2).

The following model was used for analyzing the data:

$$
Y_{i j}=X b+\sum_{m=0}^{K-1} \delta_{m} \varnothing_{m i j}+\sum_{m=0}^{K_{a}-1} \alpha_{i m} \varnothing_{m i j}+\sum_{m=0}^{K_{(i d e)}{ }^{-1}} \beta_{i m} \varnothing_{m i j}+\varepsilon_{i j}
$$

where:

$y_{i j}$ is the performance of $i^{\text {th }}$ cow.

Table 1. Statistics and structure of used data.

\begin{tabular}{cc}
\hline Number of Animals & 8515 \\
Number of Records & 68,945 \\
Number of Sires & 100 \\
Number of Dams & 7743 \\
Number of Herds & 34 \\
\hline
\end{tabular}

Table 2. Groups of days in milking (DIM) and the number of records in each group.

\begin{tabular}{ccc}
\hline Group & Days in milking & Number of records \\
\hline 1 & $5-35$ & 8076 \\
2 & $35-65$ & 8608 \\
3 & $65-95$ & 8514 \\
4 & $95-125$ & 8912 \\
5 & $125-155$ & 8393 \\
6 & $155-185$ & 7713 \\
7 & $185-215$ & 6528 \\
8 & $215-245$ & 5409 \\
9 & $245-275$ & 4157 \\
10 & $275-305$ & 2635 \\
\hline
\end{tabular}


$X$ is an incidence matrix for fixed effects.

$b$ is the vector for fixed effects.

$\delta_{m}$ is coefficient $i$ of a fixed regression on element $i$ of the polynomials of all environments.

$\alpha_{i m}, m^{\text {th }}$ degree fitting random regression for additive genetic effects for $i^{\text {th }}$ animal.

$\beta_{i m}$, is a permanent environmental effect of $I^{\text {th }}$ animal.

$\emptyset_{\text {mip }} m^{\text {th }}$ degree of fit of $j^{\text {th }}$ day for $I^{\text {th }}$ animal.

$k_{a}$ and $k_{(i d e)}$, degree of fit for additive genetic and permanent environmental effects, respectively.

$e_{i j}$ is the temporary or residual environmental random effects associated with $y^{i j}$.

Models with different order of Legendre polynomials were fitted for both the additive genetic effects and the animal permanent environmental effects. To choose the best order of fit for the random effects, the models were compared using Schwarz's Beysian Information Criterion (BIC) [11].

The variance-covariance matrix for models was assumed to be:

$$
\operatorname{var}\left[\begin{array}{l}
u \\
p \\
e
\end{array}\right]=\left[\begin{array}{lll}
\boldsymbol{G} \otimes \boldsymbol{A} & & \\
& \boldsymbol{P} \otimes \boldsymbol{I} & \\
& & \boldsymbol{R}
\end{array}\right]
$$

where:

$\boldsymbol{G}$ and $\boldsymbol{P}$ are the (co)variance matrices of the random regression coefficients for additive genetic and permanent environmental effects;

$R$ is a diagonal matrix of residual variance;

$A$ is the additive genetic relationship matrix among cows;

$I$ is an identity matrix, and $\otimes$ is the Kronecker product.

The best order of fit for additive genetic effects and animal permanent environmental effects were estimated. The restricted maximum likelihood (REML) procedure, under an average information algorithm, was used to estimate the (co)variance components and corresponding genetic parameters applying ASReml computer program [12].

\section{Result and Discussion}

Milk yield was significantly affected by the fixed effects of herd test date (HTD), milking times per day (milking frequency), number of lactations, year of birth, year of calving, age of animal at calving and days in milk (DIM) $(p<0.001)$ (Table 3).

$K=4$ was the best order of fit for the fixed regression of days in milk. Genetic analysis was started with $K=2$ for both direct additive genetic and animal permanent environmental effects and completed with higher order of fitting up to $K$ $=4$. The best model was selected using BIC (Table 4). Accordingly, a random regression model fitting Legendre polynomials to order $K=4$ for direct additive genetic effects and $K=3$ for animal permanent environmental effects was found to be the best model to describe the genetic (co) variance structure in the data. 
Table 3. Fixed effects used in the model for the analysis of milk yield with their significant level, degree of freedom, LSM and SE.

\begin{tabular}{|c|c|c|c|c|}
\hline Fixed effects & Significant level & Degree of freedom & Level & $\mathrm{LSM} \pm \mathrm{SE}$ \\
\hline \multirow{4}{*}{ Milking frequency per day } & \multirow{4}{*}{$* * *$} & \multirow{4}{*}{1} & 3 & $34.71 \pm 0.33$ \\
\hline & & & & \\
\hline & & & 4 & $36.85 \pm 0.43$ \\
\hline & & & 1 & $34.71 \pm 0.33$ \\
\hline \multirow[t]{3}{*}{ Lactation period } & \multirow[t]{3}{*}{$* * *$} & \multirow[t]{2}{*}{2} & 2 & $34 / 2 \pm 0.56$ \\
\hline & & & 3 & $33.07 \pm 0.69$ \\
\hline & & \multirow{4}{*}{3} & 2003 & $34.71 \pm 0.33$ \\
\hline \multirow{3}{*}{ Birth year } & \multirow{3}{*}{$* * *$} & & 2004 & $35.69 \pm 0.56$ \\
\hline & & & 2005 & $36.11 \pm 0.67$ \\
\hline & & & 2006 & $37.11 \pm 0.82$ \\
\hline \multirow{4}{*}{ Calving year } & \multirow{3}{*}{$* * *$} & \multirow{3}{*}{2} & 2007 & $34.71 \pm 0.33$ \\
\hline & & & 2008 & $33.71 \pm 0.54$ \\
\hline & & & 2009 & $34.97 \pm 0.66$ \\
\hline & \multirow{5}{*}{$* * *$} & \multirow{5}{*}{3} & 1 & $34.71 \pm 0.33$ \\
\hline \multirow{4}{*}{ Age } & & & 2 & $40.81 \pm 0.74$ \\
\hline & & & & \\
\hline & & & 3 & $32.4 \pm 0.51$ \\
\hline & & & 4 & $34.02 \pm 0.51$ \\
\hline \multirow{5}{*}{ Days in milking } & \multirow{5}{*}{$* * *$} & \multirow{5}{*}{3} & 1 & $34.71 \pm 0.33$ \\
\hline & & & 2 & $28.06 \pm 0.53$ \\
\hline & & & & \\
\hline & & & 3 & $31.88 \pm 0.42$ \\
\hline & & & 4 & $37.42 \pm 0.42$ \\
\hline
\end{tabular}

${ }^{* * *}: P<0.001$.

Table 4. Order of fit for direct additive genetic effects $\left(K_{a}\right)$, animal permanent environment effects $\left(K_{\text {ide }}\right)$, number of parameters $(\mathrm{Np})$, Log likelihood values $(\log \mathrm{L})$ and Bayesian Information Criterion (BIC) derived from base model (Model 1).

\begin{tabular}{cccccc}
\hline & Order of fit & & & NogL & BIC \\
\hline$K_{\mathrm{a}}$ & $\mathrm{K}_{\text {ide }}$ & & & \\
\hline 2 & 2 & 17 & 4292.67 & 8774.74 \\
3 & 2 & 20 & 4026.56 & 8275.93 \\
3 & 3 & 23 & 3929.33 & 8114.91 \\
4 & 3 & 27 & 3846.15 & $7993.09^{\mathrm{a}}$ \\
4 & 4 & 31 & 3844.09 & 8033.54 \\
\hline
\end{tabular}

${ }^{\mathrm{a} B e s t}$ model based on BIC. 


\subsection{Additive Genetic Variance}

Additive genetic variance showed an increasing rate from the first to the $9^{\text {th }}$ month of milking but it was suddenly decreased at the end of lactation period (Figure 1). Minimum $\left(5.7 \mathrm{~kg}^{2}\right)$ and maximum $\left(18.16 \mathrm{~kg}^{2}\right)$ additive genetic variance were observed in the first and $9^{\text {th }}$ month of lactation, respectively. Generally, the rate of variance changing in the first half of the milking period was less than the second half of the lactation period. The results are in agreement with the results of [13] [14], and are not in agreement with the results of [15] [16].

\subsection{Animal Permanent Environment Variance}

Animal permanent environment variance had a gradual increasing rate from the first to the $8^{\text {th }}$ month of lactation period and then sharply increased for the later months (Figure 2). Minimum (15.3 $\left.\mathrm{kg}^{2}\right)$ and maximum $\left(27.1 \mathrm{~kg}^{2}\right)$ animal permanent environment variance were observed in $2^{\text {nd }}$ and $10^{\text {th }}$ months of lactation period. References [13] [16] [17] reported a maximum animal permanent environment variance at the first two months and last two months and a minimum animal permanent environment variance in the middle months of lactation period. Also [18] [19] observed that animal permanent environment variance had increased by increasing the number of the lactation period.

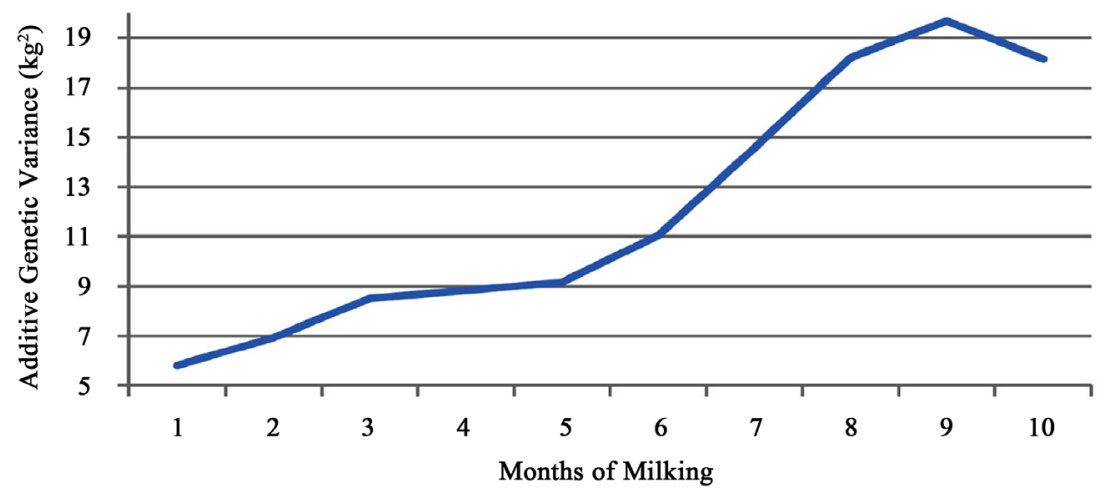

Figure 1. Additive genetic variance of milk yield during month of milking.

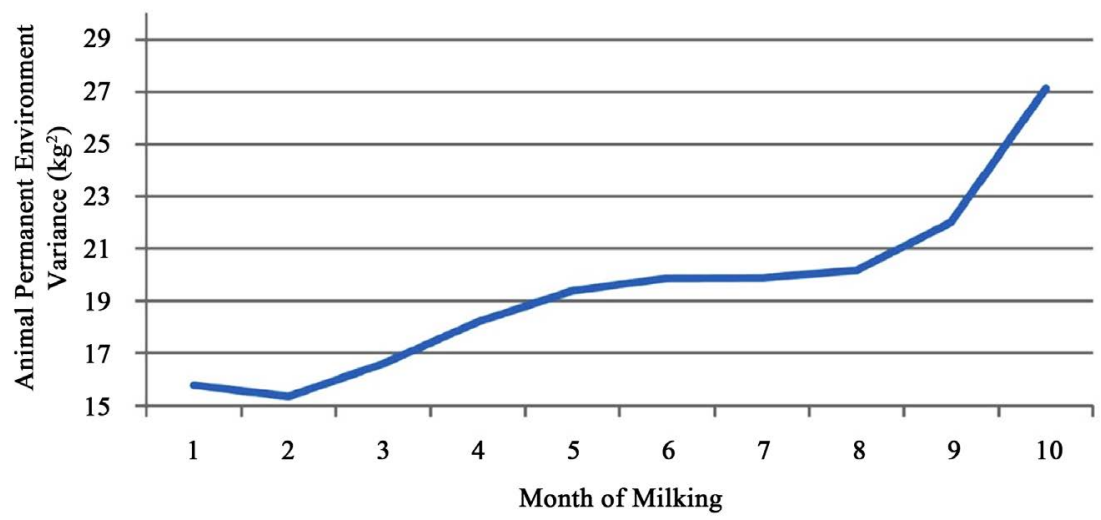

Figure 2. Animal permanent environment variance of milk yield during month of milking. 


\subsection{Residual Variance}

Residual variance had decreased up to the $6^{\text {th }}$ month of lactation period and then smoothly increased to the end of lactation period (Figure 3). Maximum residual variance $\left(31.4 \mathrm{~kg}^{2}\right)$ was observed in the first month of lactation. In a study by [20] in order to estimation of variance components of milk yield using random regression models, the residual variance had an increasing rate from beginning to the end months of lactation period that is not in agreement with the results of this study. Also, [14] [17] reported residual variance changes during the lactation period.

\subsection{Phenotypic Variance}

Phenotypic variance had a decreasing rate and reached to the minimum level $\left(45.8 \mathrm{~kg}^{2}\right)$ at the $4^{\text {th }}$ month of lactation and then showed an increasing rate to the later months of lactation period (Figure 4). Maximum level of phenotypic variance was observed in the last month of lactation period. These results are in agreement with results of [14] [16] [17] [20] but differ from those observed by [18] that phenotypic variance had a decreasing rate from beginning to the end of the lactation period.

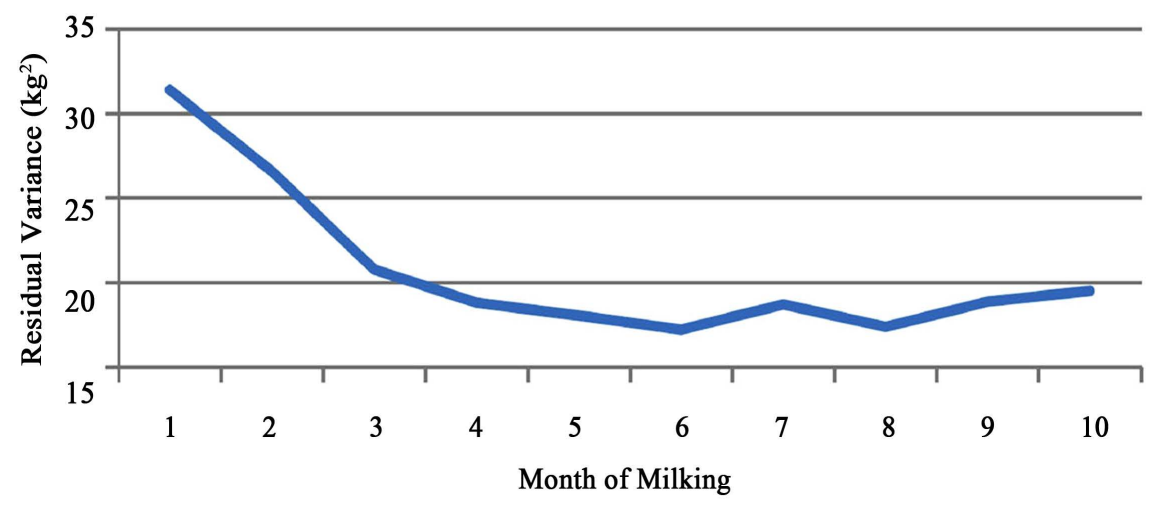

Figure 3. Residual variance for milk yield during month of milking.

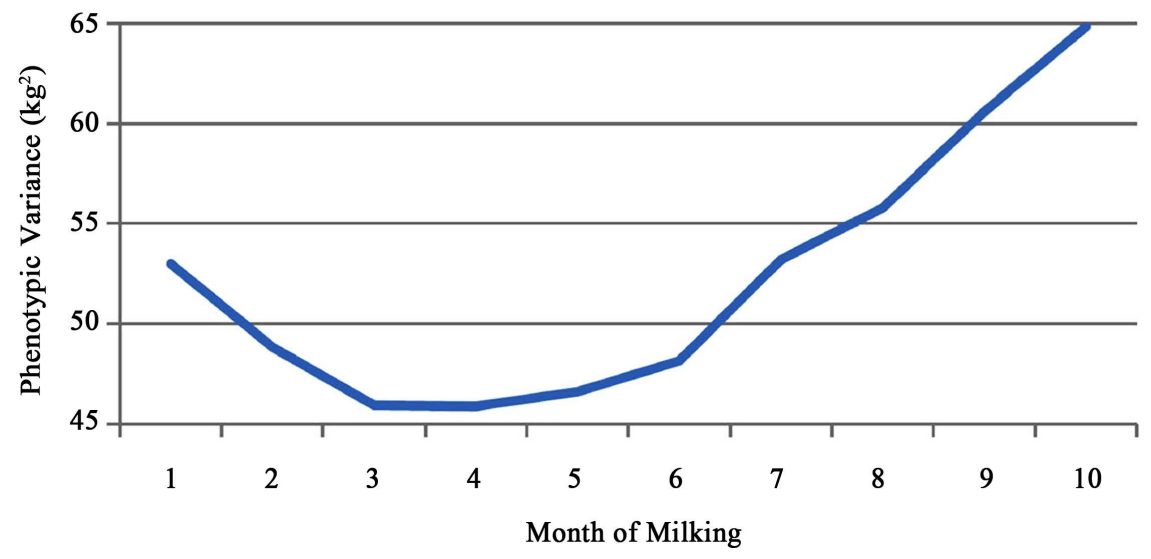

Figure 4. Phenotypic variance of milk yield during month of milking. 


\subsection{Heritability}

Heritability of milk yield estimated between 0.1 to 0.32 and it was different among months of lactation. Minimum heritability (0.1) belongs to the first month of lactation. Heritability had a gradually increasing to $3^{\text {rd }}$ month of lactation followed by smooth increasing up to $5^{\text {th }}$ month of lactation and then reaching to the highest heritability $(0.32)$ at the $8^{\text {th }}$ month of lactation through a sharp increasing rate, and finally, a slight decreasing to the $9^{\text {th }}$ and a sharper decrease in the last month of lactation (Figure 5). Low levels of heritability at the beginning months of lactation maybe duo to low additive genetic variance and higher levels of residual variance in the beginning months of lactation period. The average of estimated heritability for entire lactation period is 0.22 . These results are in agreement with those reported by [15] [18] [19] [20] [21]. Reference [22] reported minimum heritability $(0.26)$ for the first month and maximum heritability $(0.44)$ for $3^{\text {rd }}$ month of lactation period. In another study by [16] minimum heritability (0.19) was observed in the first month and the maximum heritability (0.23) was observed in the middle months of lactation period.

\subsection{Repeatability}

Repeatability for milk yield trait was estimated between 0.4 to 0.69 in the months of lactation period (Figure 6). Repeatability for milk yield trait had an increasing rate from the beginning to the end of lactation period. Minimum level and maximum level belongs to the first and last month of lactation period, respectively.

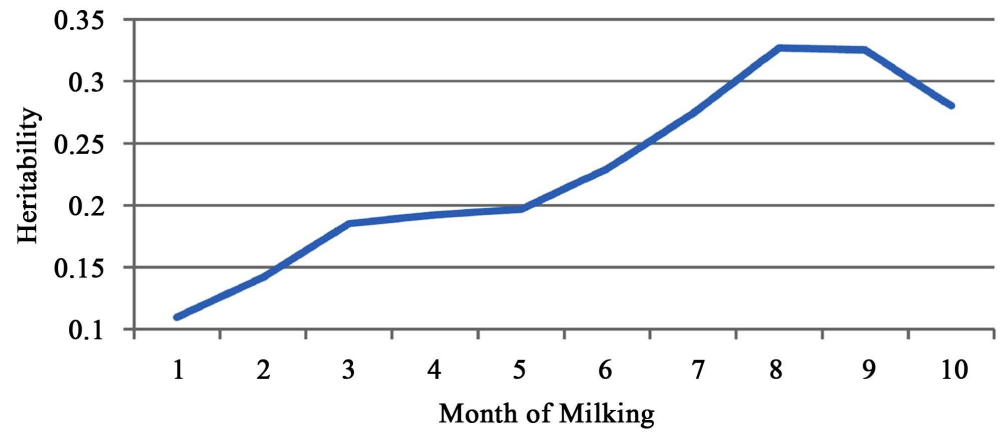

Figure 5. Heritability for milk yield during month of milking.

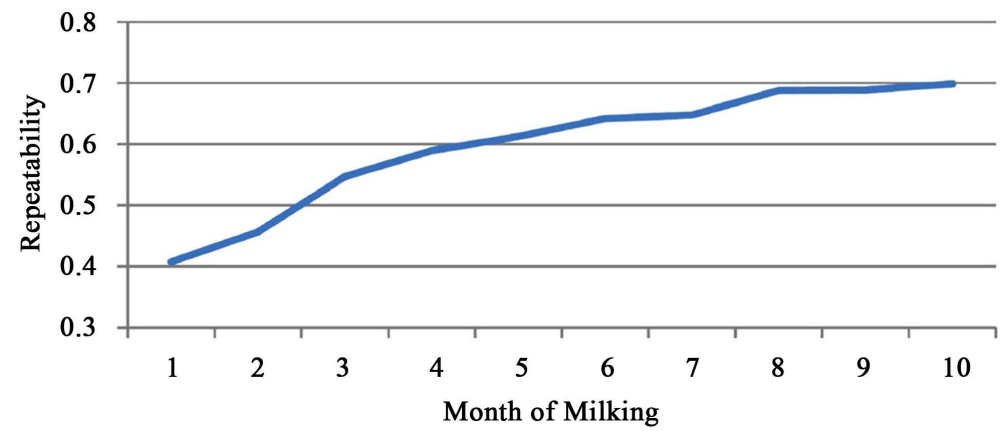

Figure 6. Repeatability for milk yield during months of milking. 


\subsection{Genetic Correlation}

Genetic correlation between months of milking estimated between -0.35 to +0.98 (Table 3). Maximum genetic correlation for milk yield trait observed between consecutive months, specially, at the end of lactation period. Genetic correlations between first month of lactation and other months (up to $6^{\text {th }}$ month) estimated between 0.8 to 0.11 that shows genetic correlation had decreased as the intervals between months of lactation increased. Negative genetic correlation shows cows with high performance in milk production at the beginning of lactation have low performance at the end of lactation period. Genetic correlation between consecutive months at the beginning of lactation was less than genetic correlation between consecutive months at the end of lactation period. Genetic correlation between first and second month of lactation was 0.8 and genetic correlation for the four latest months of lactation estimated between 0.96 to 0.98 . These results are in agreement with those reported by [13] [17] [20] [21] [22].

\subsection{Phenotypic Correlation}

Phenotypic correlation for the milk yield estimated between 0.03 to 0.67 during months of lactation (Table 5). Maximum phenotypic correlation observed between consecutive months at the end of lactation period. Phenotypic correlation estimated 0.39 to 0.48 for the first three months of lactation and 0.65 to 0.67 for the latest three months of lactation. Results of this study shows that phenotypic correlation between months of lactation had decreased by increasing the interval between months of lactation. The magnitude of phenotypic correlation was less than genetic correlation but it follows the same pattern to the genetic correlation. Estimated phenotypic correlation in this study was similar to those reported by [13] [17] [20] [22].

Table 5. Coefficients for genetic correlation (below diagonal), and phenotypic correlation (above diagonal) for milk yield in different months of lactation.

\begin{tabular}{ccccccccccc}
\hline $\begin{array}{c}\text { Month of } \\
\text { lactation }\end{array}$ & 1 & 2 & 3 & 4 & 5 & 6 & 7 & 8 & 9 & 10 \\
\hline 1 & - & 0.39 & 0.36 & 0.32 & 0.27 & 0.22 & 0.17 & 0.12 & 0.07 & 0.03 \\
2 & 0.8 & - & 0.48 & 0.46 & 0.41 & 0.34 & 0.26 & 0.19 & 0.12 & 0.07 \\
3 & 0.6 & 0.94 & - & 0.55 & 0.52 & 0.45 & 0.37 & 0.28 & 0.2 & 0.14 \\
4 & 0.44 & 0.83 & 0.95 & - & 0.58 & 0.54 & 0.47 & 0.39 & 0.31 & 0.23 \\
5 & 0.28 & 0.62 & 0.79 & 0.93 & - & 0.6 & 0.55 & 0.5 & 0.42 & 0.33 \\
6 & 0.11 & 0.33 & 0.53 & 0.74 & 0.93 & - & 0.62 & 0.6 & 0.53 & 0.44 \\
7 & -0.03 & 0.08 & 0.27 & 0.52 & 0.79 & 0.95 & - & 0.65 & 0.61 & 0.53 \\
8 & -0.14 & -0.09 & 0.09 & 0.35 & 0.65 & 0.88 & 0.98 & - & 0.67 & 0.61 \\
9 & -0.24 & -0.2 & -0.01 & 0.25 & 0.56 & 0.81 & 0.94 & 0.98 & - & 0.66 \\
\hline & -0.35 & -0.25 & -0.04 & 0.21 & 0.5 & 0.73 & 0.86 & 0.92 & 0.96 & - \\
\hline
\end{tabular}




\section{Conclusion}

This research highlighted that milk yield in Iranian Holstein cows significantly affected by milking frequency, number of lactations, year of birth, year of calving, age of animal at calving and days in milk (DIM). Also, we can conclude that additive genetic variance, animal permanent environment variance, phenotypic variance, heritability and repeatability can have different values during the lactation period. Nutrition, management, parturition stress and genotype by environment interaction in Iranian dairy cows may be the most probable factors that change the milk production curve. High magnitudes of genetic and phenotypic correlations between consecutive months of lactation indicated that similar factors (Management, Nutrition, ...) with the same pattern can affect the milk production and as the interval increases between months of lactation, the effects of these factors differ from a month to another month in the lactation period.

\section{Acknowledgements}

We are grateful to the Iranian Animal Breeding Center for providing us the data.

\section{References}

[1] Edriss, M.A., Nilforooshan, M.A. and Sadeghi, J.M. (2006) Estimation of Direct Genetic and Maternal Effects for Production Traits of Iranian Holstein Cows Using Different Animal Models. Pakistan Journal of Biological Science, 9, 636-640. https://doi.org/10.3923/pjbs.2006.636.640

[2] Edriss, M.A. and Khosravinia, H. (2000) An Introduction to Animal Breeding. In: cell, Reproduction, Growth and Development. Isfahan University of Technology Press, Iran, 11-36.

[3] Togashi, K. and Lin, C.Y. (2006) Selection for Milk Production and Persistency Using Eigenvectors of the Random Regression Coefficient Matrix. Journal of Dairy Science, 89, 4866-4873. https://doi.org/10.3168/jds.S0022-0302(06)72535-8

[4] Takma, C. and Akbas, Y. (2007) Estimates of Genetic Parameters for Test Day Milk Yields of a Holstein Friesian Herd in Turkey with Random Regression Models. Archives Animal Breeding, 50, 327-336. https://doi.org/10.5194/aab-50-327-2007

[5] Savegnago, R.P., Rosa, G.J.M., Valente, B.D., Herrera, L.G.G., Carneiro, R.L.R., Sesana, R.C., Faro, L.E. and Munari, D.P. (2013) Estimates of Genetic Parameters and Eigenvector Indices for Milk Production of Holstein Cows. Journal of Dairy Science, 96, 7284-7293. https://doi.org/10.3168/jds.2013-6708

[6] Henderson, C.R. (1982) Analysis of Covariance in the Mixed Model: Higher-Level, Nonhomogeneous and Random Regressions. Biometrics, 38, 623-640. https://doi.org/10.2307/2530044

[7] Jamrozik, J., Kistemaker, G.J., Dekkers, J.C.M. and Schaeffer, L.R. (1997) Comparison of Possible Covariates for Use in a Random Regression Model for Analyses of Test Day Yields. Journal of Dairy Science, 80, 2550-2556. https://doi.org/10.3168/jds.S0022-0302(97)76210-6

[8] Van der Werf, J.H.J., Goddard, M.E. and Meyer, K. (1998) The Use of Covariance 
Functions and Random Regressions for Genetic Evaluation of Milk Production Based on Test Day Records. Journal of Dairy Science, 81, 3300-3308. https://doi.org/10.3168/jds.S0022-0302(98)75895-3

[9] Zavadilova, L., Jamrozik, J. and Schaeffer, L.R. (2005) Genetic Parameters for Test-Day Model with Random Regressions for Production Traits of Czech Holstein Cattle. Czech Journal of Animal Science, 50, 142-154.

[10] Kim, B.W., Lee, D., Joen, J.T. and Lee, J.G. (2009) Estimation of Genetic Parameters for Milk Production Traits Using a Random Regression Test-Day Model in Holstein Cows in Korea. Asian-Australasian Journal of Animal Sciences, 22, 923-930. https://doi.org/10.5713/ajas.2009.80110

[11] Schwarz, G. (1978) Estimating the Dimension of a Model. The Annals of Statistics, 6, 461-464. https://doi.org/10.1214/aos/1176344136

[12] Gilmour, A., Gogel, B., Cullis, B., Thompson, R. and Butler, D. (2009) ASReml User Guide Release 3.0. VSN International Ltd., Hemel Hempstead.

[13] Hammami, H., Rekik, B., Soyeurt, H., Ben Gara, A. and Gengler, N. (2008) Genetic Parameters for Tunisian Holsteins Using a Test-Day Random Regression Model. Journal of Dairy Science, 91, 2118-2126. https://doi.org/10.3168/jds.2007-0382

[14] Mayeres, P., Stoll, J., Bormann, J., Reents, R. and Gengler, N. (2004) Prediction of Daily Milk, Fat, and Protein Production by a Random Regression Test-Day Model. Journal of Dairy Science, 87, 1925-1933. https://doi.org/10.3168/jds.S0022-0302(04)73351-2

[15] Bignardi, A.B., Faro, L.E., Santana, M.L., Rosa, G.J.M., Cardoso, V.L., Machado, P.F. and Albuquerque, L.G. (2012) Bayesian Analysis of Random Regression Models Using B-Splines to Model Test-Day Milk Yield of Holstein Cattle in Brazil. Livestock Science, 150, 401-406. https://doi.org/10.1016/j.livsci.2012.09.010

[16] Silvestre, A.M., Petim-Batista, F. and Colaco, J. (2005) Genetic Parameter Estimates of Portuguese Dairy Cows for Milk, Fat, and Protein Using a Spline Test-Day Model. Journal of Dairy Science, 88, 1225-1230. https://doi.org/10.3168/jds.S0022-0302(05)72789-2

[17] Bignardi, A.B., Faro, L.E., Cardoso, V.L., Machado, P.F. and Albuquerque, L.G. (2009) Random Regression Models to Estimate Test-Day Milk Yield Genetic Parameters Holstein Cows in Southeastern Brazil. Livestock Science, 123, 1-7. https://doi.org/10.1016/j.livsci.2008.09.021

[18] Guo, Z., Lund, M.S., Madsen, P., Korsgaard, I. and Jensen, J. (2002) Genetic Parameter Estimation for Milk Yield over Multiple Parities and Various Lengths of Lactation in Danish Jerseys by Random Regression Models. Journal of Dairy Science, 85, 1596-1606. https://doi.org/10.3168/jds.S0022-0302(02)74230-6

[19] Togashi, K., Lin, C.Y., Atagi, Y., Hagiya, K., Sato, J. and Nakanishi, T. (2008) Genetic Characteristics of Japanese Holstein Cows Based on Multiple-Lactation Random Regression Test-Day Animal Models. Livestock Science, 114, 194-201. https://doi.org/10.1016/j.livsci.2007.04.023

[20] Olori, V.E., Hilla, W.G., McGuirk, B.J. and Brotherstonea, S. (1999) Estimating Variance Components for Test Day Milk Records by Restricted Maximum Likelihood with a Random Regression Animal Model. Livestock Production Science, 61, 53-63. https://doi.org/10.1016/S0301-6226(99)00052-4

[21] Kettunen, A., Mantysaari, E.A. and Poso, J. (2000) Estimation of Genetic Parameters for Daily Milk Yield of Primiparous Ayrshire Cows by Random Regression Test-Day Models. Livestock Production Science, 66, 251-261.

https://doi.org/10.1016/S0301-6226(00)00166-4 
[22] Berry, D.P., Buckley, F., Dillon, P., Evans, R.D., Rath, M. and Veerkamp, R.F. (2003) Genetic Parameters for Body Condition Score, Body Weight, Milk Yield, and Fertility Estimated Using Random Regression Models. Journal of Dairy Science, 86, 3704-3717. https://doi.org/10.3168/jds.S0022-0302(03)73976-9 